\title{
Demequina aestuarii gen. nov., sp. nov., a novel actinomycete of the suborder Micrococcineae, and reclassification of Cellulomonas fermentans Bagnara et al. 1985 as Actinotalea fermentans gen. nov., comb. nov.
}

Correspondence Jongsik Chun jchun@snu.ac.kr

\author{
Hana Yi, ${ }^{1}$ Peter Schumann ${ }^{2}$ and Jongsik Chun ${ }^{1}$ \\ ${ }^{1}$ School of Biological Sciences and Institute of Microbiology, Seoul National University, \\ 56-1 Shillim-dong, Kwanak-gu, Seoul 151-742, Republic of Korea \\ ${ }^{2} \mathrm{DSMZ}$ - Deutsche Sammlung von Mikroorganismen und Zellkulturen, Inhoffenstrasse 7b, \\ D-38124 Braunschweig, Germany
}

The west and south-west coasts of the Korean peninsula consist mainly of tidal flats that are unique among other marine sediments. The high microbial diversity of Korean tidal flat sediments has been reported in culture-independent (Kim et al., 2004, 2005) and culture-dependent (Park et al., 2005; Yi \& Chun, 2006) studies. A novel actinomycete was isolated from Korean tidal flat sediment and subjected to a comprehensive taxonomic study. Here, we report the taxonomic description of this strain.

An actinomycete strain, designated JC2054 ${ }^{\mathrm{T}}$, was isolated from a tidal flat sediment sample from Ganghwa Island,

The GenBank/EMBL/DDBJ accession number for the 16S rRNA gene sequence of strain $\mathrm{JC} 2054^{\top}$ is DQ.010160.
South Korea $\left(37^{\circ} 36^{\prime} 22.3^{\prime \prime} \mathrm{N} 126^{\circ} 22^{\prime} 59.4^{\prime \prime} \mathrm{E}\right)$, using the standard dilution plating method based on marine agar 2216 (MA; Difco). The isolate was routinely cultured on MA and maintained as a glycerol suspension $(20 \%$, w/v) at $-80{ }^{\circ} \mathrm{C}$.

The 16S rRNA gene was amplified enzymically from a single colony. The primers, PCR conditions and sequencing methods used have been described elsewhere (Chun \& Goodfellow, 1995). Preliminary sequence comparison against 16S rRNA gene sequences held in the GenBank database indicated that our isolate belonged to the suborder Micrococcineae in the order Actinomycetales. The nearly complete 16S rRNA gene sequence of strain JC2054 ${ }^{\mathrm{T}}$ (1423 bp) was aligned manually against those of 
representatives of the suborder Micrococcineae using the bacterial 16S rRNA secondary structure model. The regions available for all sequences (positions 45-71 and 98-1410; Escherichia coli numbering system) showed unambiguous alignment and were used to construct phylogenetic trees. The phylogenetic trees were inferred by using the FitchMargoliash (Fitch \& Margoliash, 1967), maximum-likelihood (Felsenstein, 1981), maximum-parsimony (Fitch, 1971) and neighbour-joining (Saitou \& Nei, 1987) methods. Evolutionary distance matrices for the neighbour-joining and Fitch-Margoliash methods were generated according to the model of Jukes \& Cantor (1969). The resultant neighbour-joining tree topology was evaluated by bootstrap analyses (Felsenstein, 1985) based on 1000 resamplings. Alignment and phylogenetic analyses were carried out using the jPHYDIT program (Jeon et al., 2005; available at http:// chunlab.snu.ac.kr/jphydit) and PAUP 4.0 (Swofford, 1998), as described previously (Yi \& Chun, 2006).

On the basis of $16 \mathrm{~S}$ rRNA gene sequence analyses, strain $\mathrm{JC} 2054^{\mathrm{T}}$ showed the highest sequence similarity to Cellulomonas fermentans DSM $3133^{\mathrm{T}} \quad(94.7 \%)$ and Sanguibacter species. (94.1-94.7\%). No other taxa showed more than $94 \%$ sequence similarity to our isolate. The close relationship between strain $\mathrm{JC} 2054^{\mathrm{T}}$ and other members of the suborder Micrococcineae was also evident from the phylogenetic tree (Fig. 1). Strain JC2054 ${ }^{\mathrm{T}}$ formed a clade with C. fermentans in the neighbour-joining (with $64 \%$ bootstrap support), maximum-likelihood and maximumparsimony trees, and was recovered as a sister group of the genus Sanguibacter in the Fitch-Margoliash tree. Apart from the close relationship with strain $\mathrm{JC} 2054^{\mathrm{T}}$, C. fermentans showed the highest sequence similarities to the genera Cellulomonas (94.4-95.8\%), Oerskovia (94.2-94.7\%), Tetrasphaera (94.6\%) and Sanguibacter (94.1-94.4\%). It is evident from the phylogenetic tree (Fig. 1) that our isolate together with $C$. fermentans are not members of the genus Cellulomonas.

Cellular morphology and motility were examined by scanning-electron and phase-contrast microscopy, respectively, using cells that had been grown on MA at $30^{\circ} \mathrm{C}$ for 3 days. The presence of mycelium and spore formation were examined following growth at $30^{\circ} \mathrm{C}$ for 3 weeks on several culture media: ISP medium No. 3 (Difco) supplemented with $4 \%(\mathrm{w} / \mathrm{v})$ sea salts (Sigma), ISP medium No. 4 (Difco)

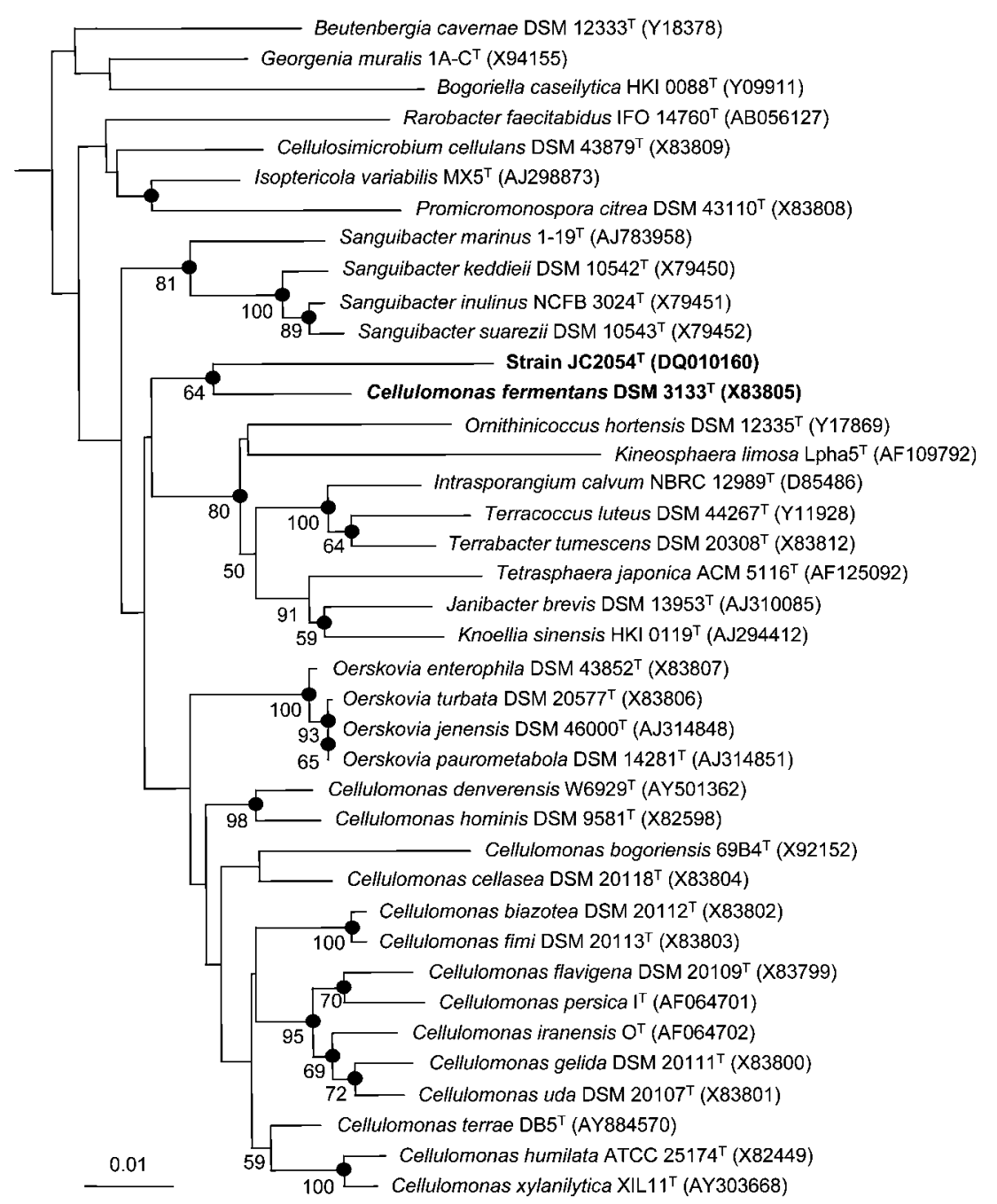

Fig. 1. Neighbour-joining tree based on nearly complete $16 \mathrm{~S}$ rRNA gene sequences. Numbers at nodes are percentage bootstrap support $(>50 \%)$ from 1000 resampled datasets. Solid circles indicate that the corresponding nodes (groupings) were recovered in more than three tree-inferring methods. Actinomyces coleocanis CCUG 41708 ${ }^{\top}$ (GenBank accession no. AJ249326), Bifidobacterium bifidum DSM $20456^{\top}$ (S83624) and Nocardia asteroides ATCC $19247^{\top}$ (Z36934) were used as outgroups (not shown). Bar, 0.01 nucleotide substitutions per position. 
supplemented with sea salts, PYGV (Staley, 1968) supplemented with sea salts, basal medium (BM; Baumann et al., 1972) and MA.

Growth under anaerobic conditions was checked using MA, in an anaerobic chamber $\left[10 \% \mathrm{CO}_{2}, 10 \% \mathrm{H}_{2}, 80 \% \mathrm{~N}_{2}(\mathrm{v} / \mathrm{v})\right.$; Sheldon Manufacturing]. The temperature range for growth $\left(5-50{ }^{\circ} \mathrm{C}\right)$, the $\mathrm{pH}$ range $(\mathrm{pH} 4-12$, adjusted with $10 \mathrm{M}$ $\mathrm{KOH}$ and $\mathrm{HCl})$ and tolerance of $\mathrm{NaCl}(0-15 \%$, w/v) were determined using synthetic ZoBell medium [Zobell, 1941; $5 \mathrm{~g}$ Bacto peptone (Difco), $1 \mathrm{~g}$ yeast extract (Difco), $0.1 \mathrm{~g}$ ferric citrate, per litre seawater] for up to 3 weeks. The optimal temperature for growth was also determined by using a temperature-gradient incubator (TVS 126MA; Advantec).

Standard physiological and biochemical tests were performed as described by Smibert \& Krieg (1994). The acidfast test was performed using Ziehl-Neelsen staining. Hydrolysis of alginic acid, casein, carboxymethylcellulose, chitin, starch and Tween 80 was tested using MA as the basal medium. DNase test agar (Difco) supplemented with $2.5 \%$ $(\mathrm{w} / \mathrm{v}) \mathrm{NaCl}$ was used for the DNase assay. Decomposition of adenine, hypoxanthine, L-tyrosine and xanthine was tested using MA, according to Gordon et al. (1974). Production of $\mathrm{H}_{2} \mathrm{~S}$ was detected using triple sugar iron agar supplemented with $2.5 \%(\mathrm{w} / \mathrm{v}) \mathrm{NaCl}$. Tests for arginine dihydrolase and $\beta$ galactosidase activities, nitrate reduction, urease activity, acid production from glucose and indole production were performed using an API 20NE kit (bioMérieux). Other enzymic activities were determined using an API ZYM kit (bioMérieux). Strips for API kits were inoculated with a heavy bacterial suspension in half-strength artificial seawater or AUX medium (bioMérieux), supplemented with $2.5 \%(\mathrm{w} / \mathrm{v}) \mathrm{NaCl}$. Carbon source utilization was tested in 96-well tissue culture microplates (Falcon) for up to 7 days using BM supplemented with $1 \%(\mathrm{v} / \mathrm{v})$ vitamin solution (Staley, 1968) as basal medium.

The results of the morphological, cultural, biochemical and physiological tests are given in the genus and species description.

Biomass for chemotaxonomy was scraped from MA plates. Extraction and gas chromatographic separation of fatty acid methyl esters were performed using the Microbial Identification System (MIDI), according to the instructions of the manufacturer. Peptidoglycan was purified and analysed according to Schleifer \& Seidl (1985). Amino acids and peptides of peptidoglycan hydrolysates were separated by two-dimensional ascending TLC on cellulose plates, using the solvent systems of Schleifer \& Kandler (1972). The molar ratios of amino acids were determined by GC and GC/MS of $N$-heptafluorobutyryl amino acid isobutyl esters (Groth et al., 1996; MacKenzie, 1987). The amino terminal amino acid of the interpeptide bridge was determined by dinitrophenylation as described by Schleifer (1985). The glycolate content of bacterial cell walls was determined by using the colorimetric method of Uchida \&
Aida (1984). Menaquinones were extracted and purified according to Collins et al. (1977) and analysed by using a modification of the HPLC method described by Groth et al. (1996) [isocratic elution from an RP 18 column (no. 201HS5415; Vydac) using acetonitrile/2-propanol $(65: 35$, $\mathrm{v} / \mathrm{v})$ at $35^{\circ} \mathrm{C}$ ] and electron-impact mass spectrometry as described by Pukall et al. (2006). The DNA G +C content was determined by HPLC analysis of deoxyribonucleosides as described by Mesbah et al. (1989). Phospholipids were extracted, purified and identified as described by Yassin et al. (1993).

The peptidoglycan of strain JC2054 ${ }^{\mathrm{T}}$ was composed of Lornithine, alanine, glycine, serine, D-glutamate and aspartate in an approximate molar ratio of $1.0: 1.2: 1.4: 1.7$ : $5.5: 0.4$. Glutamic acid represented the $\mathrm{N}$-terminus of the interpeptide bridge. The cross-linkage was of the A-type, as the characteristic peptide was L-Ala $\rightarrow$ D-Glu (Schleifer \& Kandler, 1972). L-Ornithine was the diamino acid. The major polar lipids were phosphatidylinositol, diphosphatidylglycerol and an unknown phospholipid. The fatty acid composition of strain JC2054 ${ }^{\mathrm{T}}$ was as follows: $\mathrm{C}_{14: 0}$ (1.59\%), $\mathrm{C}_{15: 0}(4.16 \%), \mathrm{C}_{16: 0}(10.42 \%), \mathrm{C}_{17: 0}(0.70 \%)$, i- $\mathrm{C}_{14: 0}(1.08 \%), \mathrm{i}-\mathrm{C}_{15: 0}(3.31 \%), \mathrm{i}-\mathrm{C}_{16: 0}(6.96 \%), \mathrm{i}-\mathrm{C}_{17: 0}$ $(0.91 \%)$, ai- $\mathrm{C}_{15: 0}(46.83 \%)$, ai- $\mathrm{C}_{17: 0}(13.14 \%), \mathrm{i}-\mathrm{C}_{15: 1} \mathrm{I}$ $(0.68 \%)$ and ai- $\mathrm{C}_{15: 1}(10.21 \%)$. The DNA G +C content was $67 \mathrm{~mol} \%$. HPLC analysis of the menaquinone composition of strain $\mathrm{JC} 2054^{\mathrm{T}}$ revealed a single component that eluted at a retention time that was earlier by $10 \%$ than that of MK-9 $\left(\mathrm{H}_{4}\right)$ extracted from Oerskovia turbata DSM $20577^{\mathrm{T}}$. The electron-impact mass spectrum of the isoprenoid quinone of strain JC2054 ${ }^{\mathrm{T}}$ clearly showed a base peak at $m / z 211$, and the peak of the molecular ion at $m / z 775$. The corresponding values for MK-9( $\left.\mathrm{H}_{4}\right)$ are $m / z$ 225 and 788, respectively. Taking an instrumental error of approximately 1 mass unit into account, this result suggests the presence of demethylmenaquinone DMK-9 $\left(\mathrm{H}_{4}\right)$ in strain JC2054 ${ }^{\mathrm{T}}$ (Collins, 1994). In contrast, the isoprenoid quinone composition of C. fermentans DSM $3133^{\mathrm{T}}$ was MK$10\left(\mathrm{H}_{4}\right)$, MK-9 $\left(\mathrm{H}_{4}\right)$ and MK-8 $\left(\mathrm{H}_{4}\right)$ in the ratio $56: 2: 1$, as revealed in this study. These results differentiate $C$. fermentans from strain $\mathrm{JC} 2054^{\mathrm{T}}$, as well as from bona fide members of the genus Cellulomonas that contain MK-9 $\left(\mathrm{H}_{4}\right)$ as the major isoprenoid quinone (Stackebrandt et al., 2002).

\section{Taxonomic conclusions}

Phylogenetic analyses based on 16S rRNA gene sequences showed that strain JC2054 ${ }^{\mathrm{T}}$ represents a distinct phyletic line within the suborder Micrococcineae of the order Actinomycetales. The highest sequence similarity values to our isolate were observed for C. fermentans DSM $3133^{\mathrm{T}}$ $(94.7 \%)$ and members of the genus Sanguibacter (94.1-94.7\%). However, strain JC2054 ${ }^{\mathrm{T}}$ could be clearly differentiated from all the phylogenetically related genera by the presence of DMK-9 $\left(\mathrm{H}_{4}\right)$, which hitherto has not been detected as a major menaquinone of members of the suborder Micrococcineae, and by several other chemotaxonomic characteristics (Table 1). It is therefore proposed 


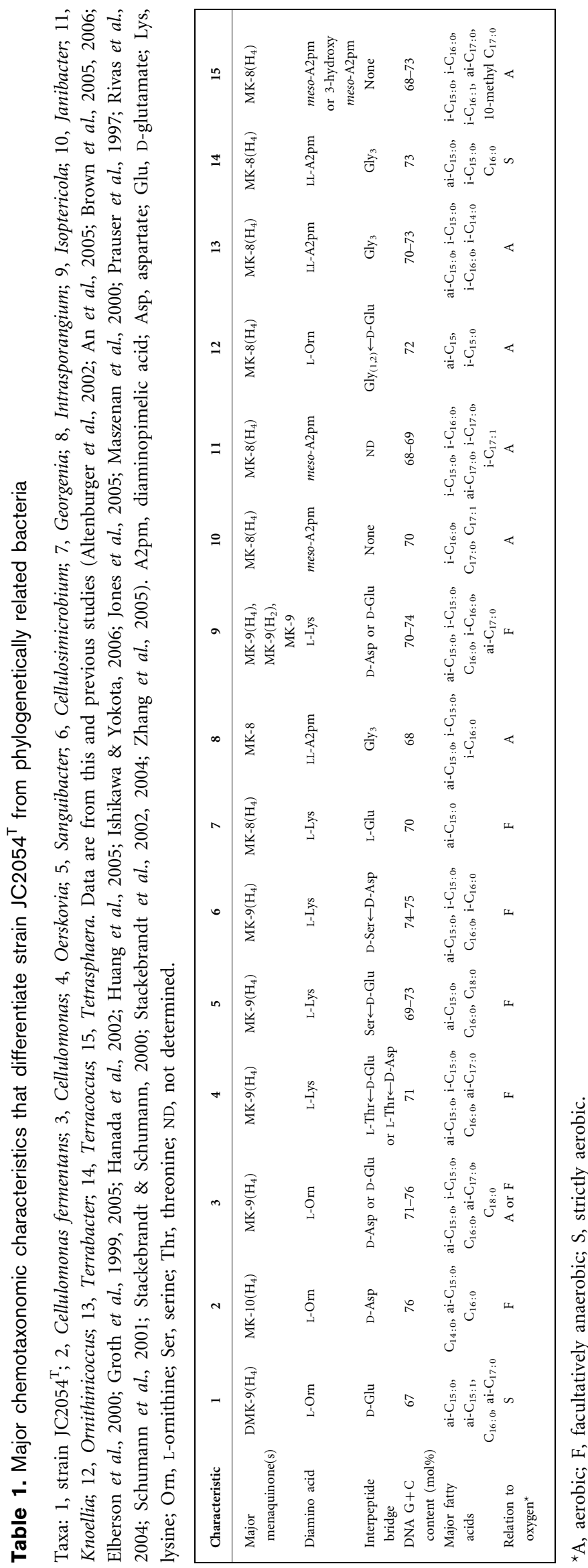

that the novel isolate should be assigned as representing a novel genus and species in the suborder Micrococcineae, with the name Demequina aestuarii gen. nov., sp. nov. In addition, on the basis of $16 \mathrm{~S}$ rRNA gene phylogeny (Fig. 1) and chemotaxonomy (Table 1), it is evident that $C$. fermentans is not a member of the genus Cellulomonas or the newly proposed genus Demequina. Therefore it is proposed that Cellulomonas fermentans should be reclassified as representing a novel genus, with the name Actinotalea fermentans gen. nov., comb. nov.

\section{Description of Demequina gen. nov.}

Demequina (De.me.qui'na. N.L. fem. n. Demequina arbitrary name derived from demethylmenaquinone, an unusual quinone found in this organism).

Gram-positive, strictly aerobic and slightly halophilic. Oxidase-negative, catalase-positive and acid-fast-negative. Do not form spores. Cells are non-motile rods with round ends. The only isoprenoid quinone is demethylmenaquinone DMK-9 $\left(\mathrm{H}_{4}\right)$. The peptidoglycan type is of the A-type of cross-linkage and contains L-ornithine, alanine, glycine, serine, D-glutamate and aspartate. L-Ornithine is the diamino acid and D-glutamate represents the $\mathrm{N}$-terminus of the interpeptide bridge. Predominant cellular fatty acids are of the anteiso-branched and straight-chain types. Major polar lipids are phosphatidylinositol, diphosphatidylglycerol and an unknown phospholipid. Phylogenetically, the genus is affiliated to the suborder Micrococcineae. The type species is Demequina aestuarii.

\section{Description of Demequina aestuarii sp. nov.}

Demequina aestuarii (ae.stu.a'ri.i. L. gen. n. aestuarii of a tidal flat, isolated from tidal flat sediment).

Exhibits the following properties in addition to those given in the genus description. Cells are $0.25-0.35 \times$ $0.60-1.20 \mu \mathrm{m}$. Growth occurs at $\mathrm{pH}$ 6-11 (optimum, $\mathrm{pH} 7)$ and in $0-12 \%(\mathrm{w} / \mathrm{v}) \mathrm{NaCl}$ (optimum, 2-4\%). Growth occurs at $5-35^{\circ} \mathrm{C}$, with optimum growth at $33.5^{\circ} \mathrm{C}$. Minimum doubling time is $6.4 \mathrm{~h}$. Extended incubation (up to 15 days) is required at $5{ }^{\circ} \mathrm{C}$. Growth occurs on MA, ISP medium No. 3 supplemented with sea salts, ISP medium No. 4 supplemented with sea salts and PYGV supplemented with sea salts, but not on Oatmeal agar supplemented with sea salts. Colonies on MA at $30^{\circ} \mathrm{C}$ are yellow, translucent and circular, with entire margins, approximately $0.2 \mathrm{~mm}$ in diameter after 2 days, with a maximum diameter of 3-4 mm after 7 days. Negative for arginine dihydrolase and urease activities. Positive for $\beta$-galactosidase activity. Nitrate is not reduced to nitrite. Does not produce $\mathrm{H}_{2} \mathrm{~S}$. Acid is not produced from glucose nor indole from tryptophan. Decomposes carboxymethylcellulose, DNA and aesculin, but not adenine, alginate, casein, chitin, gelatin, hypoxanthine, starch, Tween 80 , tyrosine or xanthine. On the basis of the API ZYM system, the organism is positive for leucine arylamidase, $\beta$-galactosidase, $\alpha$-glucosidase and 
$\beta$-glucosidase; weakly positive for naphthol-AS-BI-phosphohydrolase; negative for alkaline phosphatase, esterase (C4), esterase lipase (C8), lipase (C14), valine arylamidase, cystine arylamidase, trypsin, $\alpha$-chymotrypsin, acid phosphatase, $\alpha$-galactosidase, $\beta$-glucuronidase, $N$-acetyl- $\beta$-glucosaminidase, $\alpha$-mannosidase and $\alpha$-fucosidase. Utilizes D-cellobiose, D-fructose, D-galactose, D-glucose, D-mannitol, D-mannose, D-salicin, D-trehalose, D-xylose, glycerol, Larabinose and sucrose as a sole carbon source. Utilizes lactose weakly. Does not utilize acetamide, acetate, benzoate, citrate, D-raffinose, D-ribose, D-sorbitol, ethanol, glycine, inositol, inulin, 2-propanol, L-arginine, L-ascorbate, Lasparagine, L-lysine, L-ornithine, L-rhamnose, $\mathrm{N}$-acetylglucosamine, polyethylene glycol, salicylate, succinate, tartrate or thiamine. Major fatty acids are ai- $\mathrm{C}_{15: 0}$, ai- $\mathrm{C}_{17: 0}, \mathrm{C}_{16: 0}$ and ai- $\mathrm{C}_{15: 1}$.

The DNA G $+\mathrm{C}$ content of the type strain is $67 \mathrm{~mol} \%$. The type strain is $\mathrm{JC}^{2} 2054^{\mathrm{T}}\left(=\mathrm{IMSNU} 14027^{\mathrm{T}}=\mathrm{KCTC}\right.$ $9919^{\mathrm{T}}=$ JCM $12123^{\mathrm{T}}$ ), isolated from a tidal flat sediment sample from Ganghwa Island, South Korea.

\section{Description of Actinotalea gen. nov.}

Actinotalea (Ac.ti.no.tal'e.a. Gr. n. actis, actinis ray; L. fem. n. talea a slender staff, rod, stick; N.L. fem. n. Actinotalea ray stick).

The description is based on that given for Cellulomonas fermentans by Bagnara et al. (1985). Gram-positive. Coryneform rods exhibiting polymorphism. Non-motile. Facultatively anaerobic. Diamino acid of the peptidoglycan is $\mathrm{L}$-ornithine and interpeptide bridge is $\mathrm{D}$-aspartate. Major fatty acids are $\mathrm{C}_{14: 0}$, ai- $\mathrm{C}_{15: 0}$ and $\mathrm{C}_{16: 0}$. The major isoprenoid quinone is $\mathrm{MK}-10\left(\mathrm{H}_{4}\right)$. The type species is Actinotalea fermentans.

\section{Description of Actinotalea fermentans sp. nov., comb. nov.}

Actinotalea fermentans (fer.men'tans. L. part. adj. fermentans fermenting).

Basonym: Cellulomonas fermentans Bagnara et al. 1985.

The description is identical to that given for Cellulomonas fermentans by Bagnara et al. (1985). Cell wall sugars are glucose, rhamnose and ribose. The DNA G $+\mathrm{C}$ content of the type strain is $76 \mathrm{~mol} \%$. The type strain is DSM $3133^{\mathrm{T}}$ $\left(=\right.$ ATCC $43279^{\mathrm{T}}=\mathrm{CFBP} \quad 4259^{\mathrm{T}}=\mathrm{CIP} \quad 103003^{\mathrm{T}}=\mathrm{NBRC}$ $15517^{\mathrm{T}}=$ JCM $9966^{\mathrm{T}}=$ LMG $\left.16154^{\mathrm{T}}\right)$.

\section{Acknowledgements}

We are grateful to Professor Dr H. G. Trüper and Dr J. P. Euzéby for help with nomenclature and to Anika Wasner (DSMZ) for excellent technical assistance in production of biomass and chemotaxonomic analyses. This work was supported, in part, by the National Research
Laboratory Program and 21C Frontier Microbial Genomics and Applications Center Program, Korea Ministry of Science and Technology.

\section{References}

Altenburger, P., Kämpfer, P., Schumann, P., Vybiral, D., Lubitz, W. \& Busse, H. J. (2002). Georgenia muralis gen. nov., sp. nov., a novel actinobacterium isolated from a medieval wall painting. Int $J$ Syst Evol Microbiol 52, 875-881.

An, D.-S., Im, W.-T., Yang, H.-C., Kang, M. S., Kim, K. K., Jin, L., Kim, M. K. \& Lee, S.-T. (2005). Cellulomonas terrae sp. nov., a cellulolytic and xylanolytic bacterium isolated from soil. Int J Syst Evol Microbiol 55, 1705-1709.

Bagnara, C., Toci, R., Gaudin, C. \& Belaich, J. P. (1985). Isolation and characterization of a cellulolytic microorganism, Cellulomonas fermentans sp. nov. Int J Syst Bacteriol 35, 502-507.

Baumann, L., Baumann, P., Mandel, M. \& Allen, R. D. (1972). Taxonomy of aerobic marine eubacteria. J Bacteriol 110, 402-429.

Brown, J. M., Frazier, R. P., Morey, R. E., Steigerwalt, A. G., Pellegrini, G. J., Daneshvar, M. I., Hollis, D. G. \& McNeil, M. M. (2005). Phenotypic and genetic characterization of clinical isolates of CDC coryneform group A-3: proposal of a new species of Cellulomonas, Cellulomonas denverensis sp. nov. J Clin Microbiol 43, 1732-1737.

Brown, J. M., Steigerwalt, A. G., Morey, R. E., Daneshvar, M. I., Romero, L.-J. \& McNeil, M. M. (2006). Characterization of clinical isolates previously identified as Oerskovia turbata: proposal of Cellulosimicrobium funkei sp. nov. and emended description of the genus Cellulosimicrobium. Int J Syst Evol Microbiol 56, 801-804.

Chun, J. \& Goodfellow, M. (1995). A phylogenetic analysis of the genus Nocardia with $16 \mathrm{~S}$ rRNA gene sequences. Int J Syst Bacteriol 45, 240-245.

Collins, M. D. (1994). Isoprenoid quinones. In Chemical Methods in Prokaryotic Systematics, pp. 265-309. Edited by M. Goodfellow \& A. G. O'Donnell. Chichester: Wiley.

Collins, M. D., Pirouz, T., Goodfellow, M. \& Minnikin, D. E. (1977). Distribution of menaquinones in actinomycetes and corynebacteria. J Gen Microbiol 100, 221-230.

Elberson, M. A., Malekzadeh, F., Yazdi, M. T., Kameranpour, N., Noori-Daloii, M. R., Matte, M. H., Shahamat, M., Colwell, R. R. \& Sowers, K. R. (2000). Cellulomonas persica sp. nov. and Cellulomonas iranensis sp. nov., mesophilic cellulose-degrading bacteria isolated from forest soils. Int J Syst Evol Microbiol 50, 993-996.

Felsenstein, J. (1981). Evolutionary trees from DNA sequences: a maximum likelihood approach. J Mol Evol 17, 368-376.

Felsenstein, J. (1985). Confidence limits on phylogenies: an approach using the bootstrap. Evolution 39, 783-791.

Fitch, W. M. (1971). Toward defining the course of evolution: minimum change for a specific tree topology. Syst Zool 20, 406-416.

Fitch, W. M. \& Margoliash, E. (1967). Construction of phylogenetic trees. Science 155, 279-284.

Gordon, R. E., Barnett, D. A., Handerhan, J. E. \& Pang, C. H.-N. (1974). Nocardia coeliaca, Nocardia autotrophica, and the nocardin strain. Int J Syst Bacteriol 24, 54-63.

Groth, I., Schumann, P., Weiss, N., Martin, K. \& Rainey, F. A. (1996). Agrococcus jenensis gen. nov., sp. nov., a new genus of actinomycetes with diaminobutyric acid in the cell wall. Int J Syst Bacteriol 46, 234-239. 
Groth, I., Schumann, P., Martin, K., Schuetze, B., Augsten, K., Kramer, I. \& Stackebrandt, E. (1999). Ornithinicoccus hortensis gen. nov., sp. nov., a soil actinomycete which contains L-ornithine. Int J Syst Bacteriol 49, 1717-1724.

Groth, I., Schumann, P., Schütze, B., Gonzalez, J. M., Laiz, L., SaizJimenez, C. \& Stackebrandt, E. (2005). Isoptericola hypogeus sp. nov., isolated from the Roman catacomb of Domitilla. Int J Syst Evol Microbiol 55, 1715-1719.

Hanada, S., Liu, W.-T., Shintani, T., Kamagata, Y. \& Nakamura, K. (2002). Tetrasphaera elongata sp. nov., a polyphosphate-accumulating bacterium isolated from activated sludge. Int J Syst Evol Microbiol 52, 883-887.

Huang, Y., Dai, X., He, L., Wang, Y.-N., Wang, B.-J., Liu, Z. \& Liu, S.-J. (2005). Sanguibacter marinus sp. nov., isolated from coastal sediment. Int J Syst Evol Microbiol 55, 1755-1758.

Ishikawa, T. \& Yokota, A. (2006). Reclassification of Arthrobacter duodecadis Lochhead 1958 as Tetrasphaera duodecadis comb. nov. and emended description of the genus Tetrasphaera. Int J Syst Evol Microbiol 56, 1369-1373.

Jeon, Y.-S., Chung, H., Park, S., Hur, I., Lee, J.-H. \& Chun, J. (2005). jPHYDIT: a JAVA-based integrated environment for molecular phylogeny of ribosomal RNA sequences. Bioinformatics 21, 3171-3173.

Jones, B. E., Grant, W. D., Duckworth, A. W., Schumann, P., Weiss, N. \& Stackebrandt, E. (2005). Cellulomonas bogoriensis sp. nov., an alkaliphilic cellulomonad. Int J Syst Evol Microbiol 55, 1711-1714.

Jukes, T. H. \& Cantor, C. R. (1969). Evolution of protein molecules. In Mammalian Protein Metabolism, vol. 3, pp. 21-132. Edited by H. N. Munro. New York: Academic Press.

Kim, B. S., Oh, H. M., Kang, H., Park, S. S. \& Chun, J. (2004). Remarkable bacterial diversity in the tidal flat sediment as revealed by $16 \mathrm{~S}$ rDNA analysis. J Microbiol Biotechnol 14, 205-211.

Kim, B. S., Oh, H. M., Kang, H. \& Chun, J. (2005). Archaeal diversity in tidal flat sediment as revealed by $16 \mathrm{~S}$ rDNA analysis. J Microbiol 43, 144-151.

Mackenzie, S. L. (1987). Gas chromatographic analysis of amino acids as the $N$-heptafluorobutyryl isobutyl esters. J Assoc Off Anal Chem 70, 151-160.

Maszenan, A. M., Seviour, R. J., Patel, B. K. C., Schumann, P., Burghardt, J., Tokiwa, Y. \& Stratton, H. M. (2000). Three isolates of novel polyphosphate-accumulating Gram-positive cocci, obtained from activated sludge, belong to a new genus, Tetrasphaera gen. nov., and description of two new species, Tetrasphaera japonica sp. nov. and Tetrasphaera australiensis sp. nov. Int J Syst Evol Microbiol 50, 593-603.

Mesbah, M., Premachandran, U. \& Whitman, W. B. (1989). Precise measurement of the $\mathrm{G}+\mathrm{C}$ content of deoxyribonucleic acid by highperformance liquid chromatography. Int J Syst Bacteriol 39, 159-167.

Park, Y.-D., Baik, K. S., Yi, H., Bae, K. S. \& Chun, J. (2005). Pseudoalteromonas byunsanensis sp. nov., isolated from tidal flat sediment in Korea. Int J Syst Evol Microbiol 55, 2519-2523.

Prauser, H., Schumann, P., Rainey, F. A., Kroppenstedt, R. M. \& Stackebrandt, E. (1997). Terracoccus luteus gen. nov., sp. nov., an LL-diaminopimelic acid-containing coccoid actinomycete from soil. Int J Syst Bacteriol 47, 1218-1224.

Pukall, R., Schumann, P., Schütte, C., Gols, R. \& Dicke, M. (2006). Acaricomes phytoseiuli gen. nov., sp. nov., isolated from the predatory mite Phytoseiulus persimilis. Int J Syst Evol Microbiol 56, 465-469.
Rivas, R., Trujillo, M. E., Mateos, P. F., Martínez-Molina, E. \& Velázquez, E. (2004). Cellulomonas xylanilytica sp. nov., a cellulolytic and xylanolytic bacterium isolated from a decayed elm tree. Int J Syst Evol Microbiol 54, 533-536.

Saitou, N. \& Nei, M. (1987). The neighbor-joining method: a new method for reconstructing phylogenetic trees. Mol Biol Evol 4, 406-425.

Schleifer, K. H. (1985). Analysis of the chemical composition and primary structure of murein. Methods Microbiol 18, 123-156.

Schleifer, K. H. \& Kandler, O. (1972). Peptidoglycan types of bacterial cell walls and their taxonomic implications. Bacteriol Rev 36, 407-477.

Schleifer, K. H. \& Seidl, P. H. (1985). Chemical composition and structure of murein. In Chemical Methods in Bacterial Systematics, pp. 201-219. Edited by M. Goodfellow \& D. E. Minnikin. London: Academic Press.

Schumann, P., Weiss, N. \& Stackebrandt, E. (2001). Reclassification of Cellulomonas cellulans (Stackebrandt and Keddie 1986) as Cellulosimicrobium cellulans gen. nov., comb. nov. Int J Syst Evol Microbiol 51, 1007-1010.

Smibert, R. M. \& Krieg, N. R. (1994). Phenotypic characterization. In Methods for General and Molecular Bacteriology, pp. 607-654. Washington, DC: American Society for Microbiology.

Stackebrandt, E. \& Schumann, P. (2000). Introduction to the taxonomy of actinobacteria. In The Prokaryotes: an Evolving Electronic Resource for the Microbiological Community, release 3.3. Edited by M. Dworkin. New York: Springer. http://link.springer-ny. com/link/service/books/10125/

Stackebrandt, E., Schumann, P. \& Prauser, H. (2002). The Family Cellulomonadaceae. In The Prokaryotes: an Evolving Electronic Resource for the Microbiological Community, release 3.0. Edited by M. Dworkin, S. Falkow, E. Rosenberg, K.-H. Schleifer \& E. Stackebrandt. New York: Springer. http://link.springer-ny.com/ link/service/books/10125/

Stackebrandt, E., Schumann, P. \& Cui, X.-L. (2004). Reclassification of Cellulosimicrobium variabile Bakalidou et al., 2002 as Isoptericola variabilis gen. nov., comb. nov. Int J Syst Evol Microbiol 54, 685-688.

Staley, J. T. (1968). Prosthecomicrobium and Ancalomicrobium: new prosthecate freshwater bacteria. J Bacteriol 95, 1921-1942.

Swofford, D. L. (1998). PAUP*: Phylogenetic Analysis Using Parsimony ( ${ }^{*}$ and other methods), version 4. Sunderland, MA: Sinauer Associates.

Uchida, K. \& Aida, K. (1984). An improved method for the glycolate test for simple identification of the acyl type of bacterial cell walls. J Gen Appl Microbiol 30, 131-134.

Yassin, A. F., Haggenei, B., Budzikiewicz, H. \& Schaal, K. P. (1993). Fatty acid and polar lipid composition of the genus Amycolatopsis: application of fast atom bombardment-mass spectrometry to structure analysis of underivatized phospholipids. Int $J$ Syst Bacteriol 43, 414-420.

Yi, H. \& Chun, J. (2006). Thalassobius aestuarii sp. nov., isolated from tidal flat sediment. J Microbiol 44, 171-176.

Zhang, Y.-Q., Schumann, P., Li, W.-J., Chen, G.-Z., Tian, X.-P., Stackebrandt, E., Xu, L.-H. \& Jiang, C.-L. (2005). Isoptericola halotolerans sp. nov., a novel actinobacterium isolated from saline soil from Qinghai Province, north-west China. Int J Syst Evol Microbiol 55, 1867-1870.

Zobell, C. E. (1941). Studies on marine bacteria. I. The cultural requirements of heterotrophic aerobes. J Mar Res 4, 42-75. 